Research, part of a Special Feature on Sustainable Land-Use Practices in Mountain Regions: Integrative Analysis of Ecosystem Dynamics Under Global Change, Social-Economic Impacts, and Policy Implications

\title{
Combining Policy Network and Model-Based Scenario Analyses: An Assessment of Future Ecosystem Goods and Services in Swiss Mountain Regions
}

\author{
$\underline{\text { Christian Hirschi }}^{1}, \underline{\text { Alexander Widmer }}^{1}$, Simon Briner $^{2}$ and Robert Huber $^{3}$
}

\begin{abstract}
We argue that the often-proclaimed disregard of ex-ante assessments of the provision of ecosystem goods and services in policy-making processes is not only due to a neglect or a misinterpretation of the results of such assessments in the relevant political processes, but also due to an inaccurate inclusion of political variables into those assessments. To address this weakness, we combine a model-based scenario analysis with a policy network analysis. Analyzing the structure of the policy network and taking into account the policy preferences of the individual network actors allows us to assess the feasibility and likelihood of policy developments as derived from scenario-based modeling assessments. We demonstrate the applicability of our approach in an analysis of potential policy measures aimed at maintaining crucial ecosystem goods and services in Swiss mountain regions, with a specific focus on agriculture, which is arguably one of the most important sectors for various ecosystem goods and services in those regions. Our results show that a production-oriented agricultural policy still has strong political support and, consequently, a status-quo protection scenario is very likely. In contrast, a more environmentally friendly agricultural policy is unlikely if it leads to extensive new regulations for agricultural production. Even with a greening scenario performing best within a set of ex-ante model-based assessments of future policy options, our policy network analysis suggests that changes in agricultural policy would have to reconcile the support of the provision of nonmarketable ecosystem goods and services with market deregulation policies in order to become politically feasible.
\end{abstract}

Key Words: agricultural policy; ecosystem goods and services; ex-ante assessments; model-based scenario analysis; mountain regions; policy network analysis; Switzerland

\section{INTRODUCTION}

Agriculture and forest ecosystems in mountain regions provide a range of important services-in addition to food and timber also myriad forms of regulating and cultural services. However, these ecosystem goods and services are increasingly under stress due to ecological changes (IPCC 2001, Huber et al. 2005), unfavorable socioeconomic conditions (European Commission 2004, Stucki et al. 2004), and limited institutional capacities (Young 2002, Young et al. 2008, Hirschi 2010, Kok and Veldkamp 2011). To guarantee the provision of these crucial ecosystem goods and services in the future, policy interventions are needed to steer these processes and mitigate their negative impacts on ecosystems and society (Huber et al. 2013a). Such policy interventions require accurate assessments of the relevant ecological, socioeconomic, and political developments as well as of their potential future implications. For this purpose, impact assessments (Dilly and Pannell 2009, Bare 2011, Helming and Pérez-Soba 2011) and integrated assessments (Van Ittersum and Brouwer 2009, Bezlepkina et al. 2010) are widely used techniques to anticipate environmental consequences of socioeconomic developments and policy decisions and vice versa.
However, the use of such ex-ante assessments in actual policy decision processes has been rather limited thus far. Whereas the ecosystem goods and services concept aims for a better consideration of ecological and social complexities in environmental management (among others, see Fischer et al. 2007), the majority of ex-ante assessment tools actually used in policy processes are of a rather simple and modest type (Nilsson et al. 2008, Hertin et al. 2009). More complex tools, on the other hand, have often remained black boxes to policy makers rather than transparent analytical tools that could effectively inform policy decisions (De Smedt 2011). Also, political economists have repeatedly argued that specific sectoral interests-particularly in the agricultural sectorhave often been reluctant to develop more effective policies if they could result in a change of status quo (Swimmen and Van der Zee 1993, De Gorter and Swinnen 2002, Rausser and Goodhue 2002, Swinnen 2009, Anderson 2010).

In this article, we specifically argue that the often-proclaimed disregard of model-based ex-ante assessments of future provisions of ecosystem goods and services in policy-making processes is not only due to a neglect or misinterpretation of

\footnotetext{
${ }^{1}$ Professorship of Environmental Policy and Economics, Department of Environmental Systems Science, Swiss Federal Institute of Technology Zurich (ETH Zurich), ${ }^{2}$ Agri-food and Agri-environmental Economics Group, Department of Environmental Systems Science, Swiss Federal Institute of Technology Zurich (ETH Zurich), ${ }^{3}$ Swiss Federal Institute for Forest, Snow and Landscape Research WSL
} 
such assessments and their results in the relevant political processes, but also due to an inaccurate inclusion of political variables into those assessments. But the proclaimed better inclusion of political factors in ex-ante assessments remains a demanding undertaking. Policy interventions often have to be viewed in a wider political context. They typically represent a political compromise that results from bargaining processes between influential political interests (Imperial 1999). Also, in addition to the dynamics of the policy process, the scope of possible policy interventions is oftentimes dynamic itself, and, thus, is a "moving target" (Wittrock and de Leon 1986). To model such processes and their potential impacts on ecosystem goods and services provision as accurately as possible would require a permanent re-adjustment of the model parameters in order to follow the relevant developments, which is obviously an unrealistic task. Furthermore, and on a more fundamental level, public policy scholars have criticized the assumption of rational decision making that underlies most model-based scenario-analysis approaches (Sabatier and Jenkins-Smith 1993, Jones 1999, Davies et al. 2000, Sanderson 2002, Jones 2003).

We therefore aim to make both a conceptual and a methodological contribution to the a more accurate inclusion of political variables into ex-ante policy assessments by combining a model-based scenario analysis (Veldkamp and Lambin 2001, Westhoek et al. 2006, Verburg et al. 2010, Helming et al. 2011) with a policy network approach (Laumann and Knoke 1987, Knoke 1990, Rhodes 1997, Adam and Kriesi 2007, Knoke 2011). Empirically, we apply this novel approach to the case of Swiss agricultural policy, which is arguably one of the key policies for the future provision of ecosystem goods and services in mountain regions in Switzerland (Grêt-Regamey et al. 2008, Huber et al. 2013a).

Specifically, we investigate the following three research questions:

- What are the expected impacts of different policy scenarios for the agricultural sector in Switzerland on the provision of important ecosystem goods and services in mountain regions?

- Which policy scenario is most likely to be supported by the existing agricultural policy network?

- Given that there are differences between the policy preferences represented by the existing agricultural policy network on the one hand and simulated scenario results on the other hand, what developments would be needed in the agricultural policy network to close or minimize this gap in order to enhance a sustainable provision of important ecosystem goods and services in mountain regions?
In the following sections, we first outline our conceptual framework and the applied methods. Then, we describe the three selected policy scenarios and assess their expected impacts on the provision of agricultural ecosystem goods and services in mountain regions. This is followed by the analysis of the feasibility of each scenario in terms of the agricultural policy network in Switzerland. Based on our results, we discuss the relevant consequences for Swiss agricultural policy and the changes necessary for sustaining crucial agricultural ecosystem goods and services in mountain regions. We conclude with a critical assessment of our integrative approach.

\section{CONCEPTUAL FRAMEWORK AND METHODS}

Fig. 1 illustrates our conceptual approach. Typically, the scenario-based integrated assessment of ecosystem goods and services provision (Box 1 in Fig. 1) and policy network analysis (Box 2 in Fig. 1) are two separate research tasks even though the policy process and economic developments are in reality strongly interlinked (Rausser and Swinnen 2011). In this study, we integrate the analysis of agricultural policy making in Switzerland and an ex-ante policy assessment of ecosystem goods and services provision in mountain regions in three steps. Firstly, we formulate three consistent agricultural policy scenarios (status quo, liberalization, greening) based on the IPCC (2000) scenarios and four consistent, national-level scenarios for Switzerland. Each scenario specifically addresses the three main political issues in the ongoing agricultural policy reform process in Switzerland, i.e., the question of better access to the agricultural market, the level of domestic support for the agricultural sector, and the extension of more targeted support for ecosystem goods and services in the form of "greening" the agricultural policy. Secondly, each scenario is implemented in a model-based assessment of global change impacts on the provision of ecosystem goods and services in two selected Swiss mountain regions, and each is then assessed with regard to its political feasibility and likelihood given the structure of the Swiss agricultural policy network and the policy preferences of the relevant political actors. This comparison between the model output and the policy assessment allows us to identify potential variations between the modeled ecosystem goods and services provision based on the scenarios on the one hand and on the policy preferences and political structures as represented in the policy network on the other. Based on the specification of these variations, we can then-in a third step-draw conclusions about the potentially necessary policy and/or the policy network changes for improving sustainable ecosystem goods and services provision in Swiss mountain regions.

Below we describe each of these analytical steps and the underlying methodological approach in more detail. 
Fig. 1. Conceptual framework.

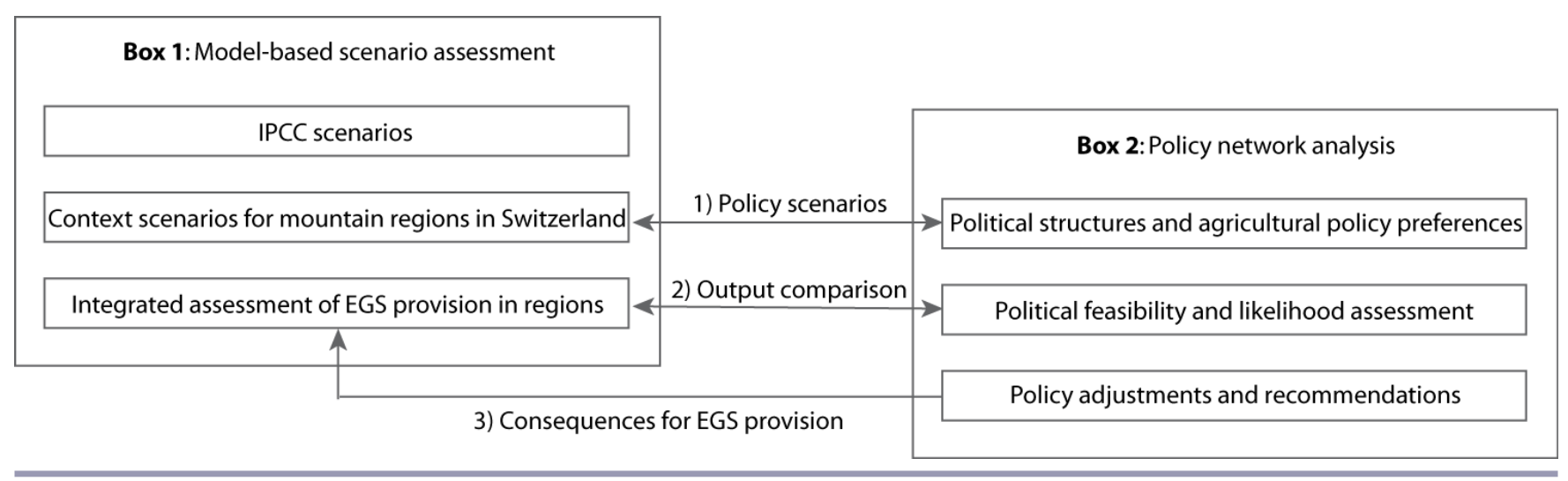

\section{Model-based assessment of the provision of mountain ecosystem goods and services}

\section{Modeling approach}

Integrated assessments and modeling frameworks can be used to evaluate alternative scenarios before the introduction of new policies as ex-ante assessments of potential policy implications (Van Ittersum and Brouwer 2009). Thereby, economic, ecological, and social consequences of a new policy are generally taken into account. To assess the impacts of three policy scenarios (described in detail below) on the provision of ecosystem goods and services in our case study regions, we use a spatially explicit, agent-based, land-use model for alpine regions. The model is based on the sector-based dynamic land allocation model ALUAM (Briner et al. 2012) which has been modified to integrate different agents representing farmers (or groups of farmers) and their attitudes and preferences (Huber et al. 2013b). The goal of the extended ALUAM-AB (ALUAM Agent-Based) is to understand agricultural land-use changes triggered by market and policy changes and to quantify the changes in ecosystem goods and services provision on a landscape scale. The model is defined by interconnected human and environmental/agronomic subsystems.

The human subsystem is defined by farm agents, including variables for household composition, available resources (land, capital, and labor), and household preferences for agricultural activities. An agent's decision mechanism is represented by an income optimization approach that governs the allocation of the agent's available resources to production while considering natural and farm structural constraints as well as incentives and regulations from market and policy scenarios. Existing production capacities are considered as sunk costs representing path dependencies on farms. Economic interactions among the farm agents are represented by a land market module (Huber et al. 2013b).
The environmental/agronomic subsystem is characterized by the agricultural production cycle in the case study area. Agronomic variables include plant nutrient requirements (N, $\mathrm{P})$, manure production, and production coefficients such as fodder intake, growth, birth, deaths of animals and labor requirements that are based on national average data (Briner et al. 2012). In the modeled farm decision process (income optimization), the environmental variables are considered as material (fodder and nutrients) balances that link land-use activities with livestock activities. As a result, land-use intensities can be defined in a spatially explicit manner. Crop rotation requirements and a labor balance are additional constraints that link the human and environmental/agronomic subsystems.

The impacts of policy scenarios were modeled up to the year 2030. To assess the future provision of ecosystem goods and services (aesthetic landscapes, $\mathrm{CO}_{2}$ balance, nitrogen emissions, habitat diversity, and food provision), we compared our modeling results with indicators for policy goals as they have been formulated by the federal public administration (FOAG and FOEN 2008).

\section{Case study regions}

We applied the model to two case study regions in Swiss mountain areas that differ with respect to natural conditions and farm structures.

The study region of Visp is located in a continental inneralpine mountain area, with an elevation ranging from 648 to $4010 \mathrm{~m}$. The region is rather dry; it has the least annual precipitation in Switzerland $(<600 \mathrm{~mm} / \mathrm{y})$. The modeled area is $443.3 \mathrm{~km}^{2} ; 16 \%$ thereof is used for agriculture. In 2008 , there were 186 active farms in the region, each averaging 9.6 ha (FOAG and FOEN 2008). Thus, farms in this region are small, and part-time farming has had a long tradition. In the ALUAM-AB model for this region, the farm agent represents 
a group of farmers with similar preferences and household compositions. Data on these agent-specific variables were collected through a standardized postal survey. The predominant products of the farms in the Valais region are milk and meat (from sheep and suckler cows).

The study region in the Jura Mountains is located at the SwissFrench boarder in the west of Switzerland. It is an oceanic mountain region at an elevation of $1200 \mathrm{~m}$, with $30 \%$ of the area being agricultural. In this region, we studied a local community of eight farmers whose farms averaged 49 ha, which is larger than the Swiss average. In the applied ALUAM-AB model, agents in the Jura region represent individual farmers. Data for the agent-specific variables are based on semistructured, face-to-face interviews. On the studied farms, all farmers work full time on their farms. Milk production is the dominant agricultural activity in this region.

\section{Policy scenarios}

For the assessment of future ecosystem goods and services provision in mountain regions we elaborated three policy scenarios that are specifically formulated for the Swiss agricultural sector and which reflect the crucial policy issues in the ongoing agricultural policy process. The policy scenarios are consistent with national-level scenarios developed by the MOUNTLAND project (Huber et al. 2013c), which present potential pathways for national-level demographic development, socioeconomic dynamics, and land use policy developments in relation to changing climate conditions based on global greenhouse emission scenarios (IPCC 2000, Abildtrup et al. 2006).

\section{Scenario 1: status quo}

Our status-quo policy scenario for the Swiss agricultural sector is in accordance with the A2 scenario of the IPCC SRES which sees an increasing importance for regional centers with national implications that are characterized by a focus on selfreliance and the preservation of local conditions. In accordance with such a policy scenario, domestic support for the agricultural sector remains, overall, at current levels. The policy also includes production-oriented support such as payments per head for animals and/or payments related to specific crops. Ecological restrictions are linked to the fulfillment of the proof of ecological performance. Overall, the total amount of financial transfer from the taxpayers to the farmers (via the official federal governmental budget) is assumed to be maintained at a high level. In addition, market access remains restricted, including tariffs and import quotas for grains and meat, respectively. As a consequence, agriculture (farm-gate) production prices in Switzerland remain higher than in neighboring countries, resulting in considerably higher consumer prices.
Scenario 2: liberalization

The scenario of liberalization most likely takes place in a national-level and a global context of economic growth and increasing international convergence, as described in the IPCC's A1FI scenario. In Swiss agricultural policy, the direct payment system is expected to be adjusted to the prescriptions of the World Trade Organization, with a possibility of a further liberalization of international markets within the World Trade Organization and/or a European framework. That is, only direct payments with no- or at most minimal—trade and production support would be in place. Thus, the overall amount of financial transfer from the taxpayers to the farmers will be reduced. As a result of the abolishment of tariffs and quotas, Swiss prices for agricultural commodities decline to the future prices on the European level.

Scenario 3: greening

The greening policy scenario is characterized by an emphasis on strengthening sustainable ecological development and appropriate economic and social changes, as per the B1 and B2 scenarios of the IPCC SRES. Domestic support (direct payment system) would be reformed with a focus on ecological performance. Payments that remunerate the fulfillment of high ecological requirements (e.g., payments for less intensive agricultural activities) are expected to increase, even if the overall financial transfers from the taxpayer to the farmer remain at current levels. With respect to market access, the level of support in Swiss agriculture is reduced. Prices for agricultural commodities decline significantly but at a lower rate than in the liberalization scenario. This gives farmers more time to adapt to new circumstances, preventing them from making fast changes in production that could have a negative impact on the provision of ecosystem goods and services. However, some of the market instruments such as product standard regulations are still in place (e.g., for animal production methods that are forbidden in Switzerland). As a consequence, agricultural commodity prices will be lower than in the protection scenario but higher than those under the liberalization scenario.

\section{Policy network analysis}

\section{Policy structures and preferences}

In addition to the impact assessment of the three policy scenarios on the provision of ecosystem goods and services, we examined the political feasibility and likelihood of the three scenarios given the structure of the agricultural policy network and the preferences of the agricultural policy actors in Switzerland. Policy network studies of the agricultural sectors in European countries go back to the early 1990s when scholars analyzed the first major liberalization steps in countries such as Britain (Smith 1990), Austria and Switzerland (Sciarini 1994), Sweden (Daugbjerg 1997), Finland (Jokinen 1997), and Denmark (Daugbjerg 1998). Coleman and colleagues 
Table 1. Policy process delimitation and network characteristics.

\begin{tabular}{llll}
\hline \hline Stage & Formulation & Decision & Overall \\
\hline Start & Decision of Federal Council to & Referral of proposal to & Decision of Federal Council to \\
& start consultation & Parliament & start consultation \\
& 14 Sep 2005 & 17 May 2006 & 14 Sep 2005 \\
End & Decision of Federal Council on & Final decision of Parliament on & Final decision of Parliament on \\
& proposal & reform package & reform package \\
& 17 May 2006 & 22 June 2007 & 22 June 2007 \\
Length of stage & 246 days & 402 days & 647 days \\
Number of actors & 22 & 19 & 28 \\
\hline
\end{tabular}

(1996) have shown in a comparative study of the United States, Canada, and Australia how paradigmatic shifts in agricultural policy can result from a series of negotiations between state actors and group representatives of the agricultural sector. For European countries, Kriesi et al. (2006) demonstrated in a more recent study the increasing importance of the European Union's policies for domestic agricultural politics.

To analyze the current agricultural policy network in Switzerland, we applied the Actor-Process-Event Scheme (APES) developed by Serdült and Hirschi (2004) and Widmer et al. (2008). According to this conceptualization, every policy process can be understood as a sequence of linked political events in which political actors participate to various degrees. The resulting systematization of the agricultural policy process can be understood and formalized as an actor-event or affiliation network and then analyzed using network analytical concepts and techniques (Wasserman and Faust 1994:291-343, Borgatti and Halgin 2011). Specifically, we calculated network variables at the level of the whole agricultural network as well as at the actor and tie level. At the network level, we measured the network's density and centralization to assess to what degree its overall structure is dependent on the position of the most central actors. These two indicators were used in previous studies to identify and characterize a so-called "policy community" in national agricultural policy sectors (Smith 1990, Coleman et al. 1996). At the level of individual actors and their relationships (ties), we used the degree of reciprocity and transitivity as additional indicators for network closure. A high degree of network closure-that is, a network with high density and mutual relationships among its members-builds up trust and mutual support, which generally increases the network's stability and its capacity to resist external attempts of interference (Daugbjerg 1997).

Empirically, we first collected all available information (from official documents and media reports) on the most recently implemented agricultural reform in Switzerland (Agricultural Policy 2011, AP 2011), developed a detailed chronology of all related and observed political events (expert hearings, official consultations, committee meetings, administrative and governmental decisions, parliamentary sessions), and assigned the participating actors (Appendix 1) and their form of interaction to the identified political events. The resulting dyadic data with the specified forms of interactions that link pairs of actors was then aggregated to a policy network as delimited in Table 1. All data transformations and network analyses were done in UCINET 6.4 (Borgatti et al. 2002).

\section{Political feasibility and likelihood assessment}

To assess a policy network's disposition for change, a structural analysis alone is not sufficient (for a recent discussion see Henry 2011). To analyze the structural characteristics of the Swiss agricultural policy network in conjunction with the three policy scenarios, we therefore integrated the policy preferences of the network actors into our assessment. Based on Laver (2001) we understand the policy preferences of political actors as "their positions on matters of public policy", that is, in our specific case the discussed policy issues of maintaining the current domestic support of the agricultural sector (status quo) as well as potential policy reforms of further deregulation (liberalization) or ecologization (greening) of the sector.

Empirically, we proceeded as follows. In a first step, we identified the crucial policy issues of the AP 2011 reform and described them with respect to domestic support (product and export subsidies), access to agricultural market (domestic market support, trade barriers), and the greening of agriculture (advancement of payments for ecological services; ecological product standards). We then coded the network actors' policy preferences on these issues based on their consultation reports on the AP 2011 governmental proposal (Appendices 2, 3, and 4).

In a second step, the coded policy preferences were integrated as actor attribute data into the policy network analysis. We used a core-periphery model (Borgatti and Everett 1999) that distinguishes centrally positioned actors in the policy network from rather peripheral actors based on their connections to other actors in the network. Based on this model, we examine what policy preferences the core actors of the network have shown and which preferences are, rather, represented in the periphery of the policy network. 
Table 2. Scenario-based ecosystem goods and services provision and public support in the Jura. $\dagger$

\begin{tabular}{|c|c|c|c|c|c|}
\hline \multirow[b]{2}{*}{ Ecosystem goods and services } & \multirow[b]{2}{*}{ Indicator } & \multirow[b]{2}{*}{$\begin{array}{c}\text { Policy goal } \\
\text { (\%) }\end{array}$} & \multicolumn{3}{|c|}{ Full-time farmers } \\
\hline & & & $\begin{array}{l}\text { Protection } \\
(\%)\end{array}$ & $\begin{array}{c}\text { Liberalization } \\
(\%)\end{array}$ & $\begin{array}{c}\text { Greening } \\
(\%)\end{array}$ \\
\hline Provision function & Food production in wheat equivalent & 100 & 74 & 19 & 41 \\
\hline Climate regulation & $\mathrm{CO}_{2}$ equivalent in 2010 & 80 & 88 & 22 & 98 \\
\hline Nutrient cycling & $\mathrm{Kg} \mathrm{NH}_{3}$ in 2010 & 50 & 84 & 24 & 105 \\
\hline Habitat diversity & Ecological area in $\%$ of total area 2010 & 100 & 130 & 114 & 250 \\
\hline Beauty and tourism & Open landscape in $\%$ of total area 2010 & 100 & 100 & 44 & 100 \\
\hline Public support for agriculture & & & 84 & 9 & 92 \\
\hline
\end{tabular}

$\uparrow$ Shaded boxes indicate that the policy goals formulated by the federal publication administration (FOAG and FOEN 2008) are not achieved.

In a third step, the policy network structure and the policy preferences were institutionally contextualized. Specifically, we focus on the possibility of a referendum (effectively taken after a policy decision has been made or hypothetically used as a strategic threat during policy formulation) as a key "veto point" in Swiss politics (Immergut 1992, Fischer 2003). To take the veto power of the policy network actors in the potential situation of a referendum into account, we included two additional actor characteristics as additional attribute data for nonstate actors into our analysis (Appendix 5): 1) the "organizational capacity" of an actor to collect the required signatures for a potential referendum, operationalized by the size of the membership of an organization; and 2) the general "reputational power" of an actor at the level of the whole political system, i.e., the political resources an actor has to effectively run a national referendum campaign successfully (Fischer et al. 2009).

The identification of the structural characteristics of the policy networks, the policy preferences represented in the network by various actors and the actors' power to actually push them through the policy process allowed us then to assess the likelihood for the policy network to change into one of the directions as represented by the different policy scenarios.

\section{Possible policy adjustments and recommendations}

The policy network's dependence on its central actors (density and centralization), the policy preferences of the relevant actors (support of or opposition to specific policy issues), as well as the actors' organizational capacity and general reputational power (veto power) are seen as important parameters for the political feasibility and likelihood of possible policy scenarios. Based on this assessment, the parameters could then be used to adjust the policy variables of the integrated assessment of ecosystem goods and services provision in order to derive a more accurate model, thus better taking into account the current political conditions. Alternatively, by using the output of the integrated assessment as a normative benchmark, policy recommendations could be formulated to modify current policies in order to enhance the sustainable provision of ecosystem goods and services.

\section{RESULTS}

We now turn to the results of our different analytical steps. First, we address the question of the expected impacts of the three policy scenarios on the provision of agricultural ecosystem goods and services.

\section{Impacts on the provision of agricultural ecosystem goods and services in mountain regions}

The model-based assessment revealed heterogeneous results with respect to the different ecosystem goods and services assessed in the two study areas (Tables 2 and 3).

Food production is expected to be reduced in all three scenarios for both regions, which-in general-will increase the provision of nonmarketable ecosystem goods and services. As a consequence of a decreasing number of animals, greenhouse gas and ammoniac emissions are expected to decrease too, whereas the share of ecological areas (i.e., extensively cultivated grassland) would increase in the Visp region. In the Jura region, however, simulations predict a future increase of greenhouse gas and ammoniac emissions even for the greening scenario. These modeling results can be explained by the concomitant effects of the assumed acreage-based direct payments and a reduction of farm-gate prices. Lower prices trigger a shift from milk to meat production (heifers), which decreases fodder demand. If direct payments remain high, farmers will increase the number of heifers to maintain the agricultural area.

The degree of the reduction in food provision in our model is driven by the market access policy assumption in our scenarios. Based on the assumption of European farm-gate prices for Swiss agriculture-as is the case in the liberalization scenario-food production is expected to be reduced by $81 \%$ (Jura) and 75\% (Valais). In the greening scenario, simulations show a reduction of $60 \%$. However, food production is also reduced in the status quo-oriented protection scenario. This 
Table 3. Scenario-based ecosystem goods and services provision and public support in the Valais. $\dagger$

\begin{tabular}{|c|c|c|c|c|c|}
\hline \multirow[b]{2}{*}{ Ecosystem goods and services } & \multirow[b]{2}{*}{ Indicator } & \multirow[b]{2}{*}{$\begin{array}{c}\text { Policy goal } \\
(\%)\end{array}$} & \multicolumn{3}{|c|}{ Part-time farmers } \\
\hline & & & $\begin{array}{l}\text { Protection } \\
\quad(\%)\end{array}$ & $\begin{array}{c}\text { Liberalization } \\
(\%)\end{array}$ & $\begin{array}{c}\text { Greening } \\
(\%)\end{array}$ \\
\hline Provision function & Food production in wheat equivalent & 100 & 82 & 35 & 41 \\
\hline Climate regulation & $\mathrm{CO}_{2}$ equivalent in 2010 & 80 & 74 & 43 & 47 \\
\hline Nutrient cycling & $\mathrm{Kg} \mathrm{NH}_{3}$ in 2010 & 50 & 68 & 44 & 49 \\
\hline Habitat diversity & Ecological area in $\%$ of total area 2010 & 100 & 181 & 215 & 193 \\
\hline Beauty and tourism & Open landscape in $\%$ of total area 2010 & 100 & 99 & 100 & 100 \\
\hline Public support for agriculture & & & 79 & 68 & 105 \\
\hline
\end{tabular}

$\uparrow$ Shaded boxes indicate that the policy goals formulated by the federal publication administration (FOAG and FOEN 2008) are not achieved.

can be explained by our assumptions of increasing production cost on the one hand and by the effect of less intensive landuse triggered by structural change at the farm level on the other. The degree of changes in nonmarketable ecosystem goods and services such as climate regulation, nutrient cycling, and habitat diversity is strongly correlated to the reduction in food production due to the jointness in production between marketable and nonmarketable ecosystem goods and services in our modeling approach.

With respect to the maintenance of an open landscape, our findings indicate that acreage-based direct payments can compensate for the reduction in prices in the Jura region. Without these payments, more than half of the area is expected to be abandoned in the liberalization scenario. In contrast, the liberalization scenario does not lead to land abandonment in the Valais. This effect can be explained by the initial farm structure and the corresponding attitudes of the part-time farmers living in this region. Part-time farmers are less dependent on agricultural income. Furthermore, the farmers have stated in our survey that they will continue to farm their land even when the income from agricultural production is low.

In summary, the modeled liberalization scenario results in a massive reduction of public support for the agricultural sector and an increase in nonmarketable ecosystem goods and services at the expense of food production in both regions. In contrast, the protection scenario shows the least impact on agricultural production, and, thus, would miss greenhouse gas and ammoniac reduction targets in the Jura region and the ammoniac target in the Valais. In addition, public support remains high. This result holds also with respect to the greening scenario, which performs best in the provision of less intensively used ecological areas. However, emission targets would still be missed in the Jura region.

Given the trade-offs in the provision of different ecosystem goods and services, no scenario could fulfill all the policy goals formulated by the federal public administration (FOAG and
FOEN 2008). Technological change and an increase in productivity beyond the assumptions in the model might reduce this gap. However, our findings suggest that the differences in the provision of ecosystem goods and services in the two regions-based on natural conditions, initial farm structure, and the corresponding attitudes-will remain.

\section{Policy network analysis}

The policy network that has formed during the formulation and decision-making stages of the AP 2011 reform process is displayed in Fig. 2. Each individual representation of the policy network shows the network structure combined with the actors' policy preferences regarding the three identified key issues of Swiss agricultural policy. The network itself has mainly been shaped by two key elements of the process: firstly, by the broad consultation process that took place at the end of the year 2005 and in the beginning of 2006 with the Federal Office for Agriculture (FOAG), the responsible ministry (Department of Economic Affairs, DEA), and the Federal Council (FC) being the central actors; and secondly, during the stage of the parliamentary deliberation and decision making on the governmental reform proposal, by the negotiations in and between the responsible parliamentary committees (PNC and PCS) and the two chambers of the parliament (NC and CS). The political parties and main interest organizations are embedded in the policy network to various degrees. The main sectoral interest organization (Swiss Farmers' Association, SBV) is centrally positioned in the network and has close connections to both the federal public administration (mainly represented by DEA and FOAG) and the government (FC) and-via its parliamentary representatives-to the two chambers of the federal parliament. The political parties are, rather, positioned at the periphery of the network, even though they are certainly the main actors in parliament and, therefore, are also included in the parliamentary bodies of NC, CS, PNC, and PCS.

Table 4 shows the measurements for the two indicators for network density and centralization that have been used in 
Fig. 2. Policy network structure and policy positions.

\section{'Domestic support':}
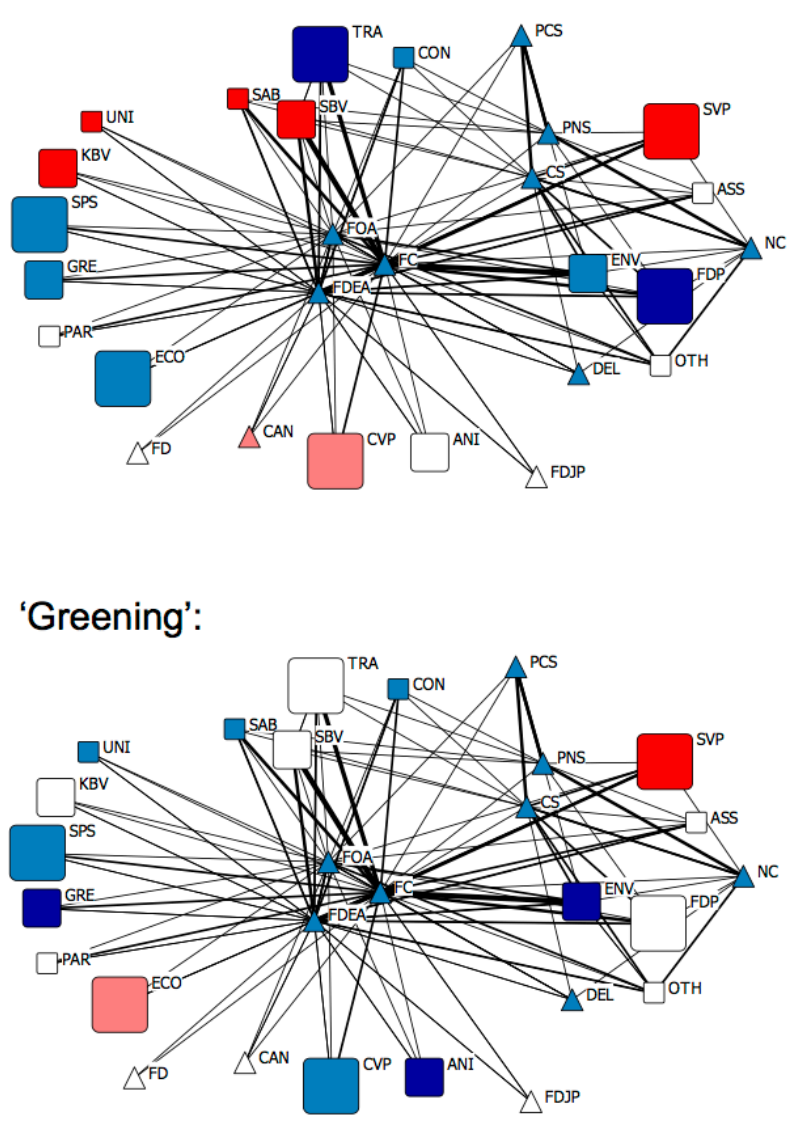

\section{'Market access':}

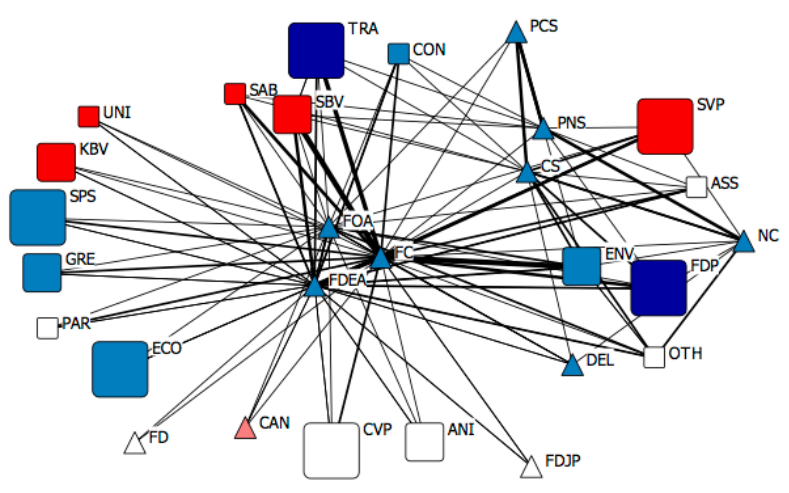

Legend:

Actor colors: policy preferences on the issues of 'domestic support', 'market access' and 'greening' in the realm of AP 2011.

strong support for issue

moderate support for issue

moderate opposition against issue

strong opposition against issue

no/indifferent preference

Size of actors: formal veto power (high, moderate, low) for non-state actors (squares) in the political process. Triangles: state actors.

Thickness of line: tie strength based on number of observed interactions between two actors in the realm of the AP 2011 policy process.

For a list of actors with acronyms see Appendix 1. previous studies to assess the existence of a "policy community". The indicators reveal the sector's strong focus on the government's AP 2011 proposal. In particular, the formulation stage is almost entirely dependent on the central actors from the government and the federal public administration (FC, DEA, and FOA). These three actors steered the formulation process, as expressed by the high centralization of the policy network at that particular stage. During decision making in parliament, the network became denser and centralization decreased, which corresponds to the broadening of the political process during the parliamentary negotiation on the reform package. In addition, the measurements for reciprocity and transitivity show-rather surprisingly - a relatively low level of network closure, even though the mixed results for reciprocity and transitivity for the two analyzed network stages do not indicate a clear tendency.
In sum, the structural analysis of the agricultural policy network shows how the policy process was strongly shaped by the most central actors representing the executive and federal administration (during formulation) and legislative (decision-making) branches of the federal government. However, the policy network does not reveal a clear tendency to network closure, indicating a more open policy process than was initially assumed based on previously found "policy communities" in European agricultural policy sectors of the 1980s and 1990s.

\section{Assessment of future scenarios considering the policy network variables}

To assess the potential impacts of the structural characteristics of the policy network on the different scenarios for ecosystem goods and services provision in the future, we considered the policy preferences of the relevant political actors. 
Table 4. Network cohesion in reform formulation and decision making.

\begin{tabular}{|c|c|c|c|}
\hline Stage $\dagger$ & Formulation & Decision & Overall \\
\hline $\begin{array}{l}\text { Network size (no. of } \\
\text { actors) }\end{array}$ & 22 & 19 & 28 \\
\hline Network density (\%) & 0.17 & 0.21 & 0.17 \\
\hline (no. of ties) & $(79)$ & $(72)$ & (128) \\
\hline $\begin{array}{l}\text { Degree centralization } \\
(\%)\end{array}$ & 0.82 & 0.66 & 0.80 \\
\hline Reciprocity (\%) & 0.36 & 0.18 & 0.31 \\
\hline Transitivity (\%) & 0.25 & 0.45 & 0.29 \\
\hline \multicolumn{4}{|c|}{$\begin{array}{l}\dagger \text { Network density is defined as proportion of observed relations in } \\
\text { relation to all possible relations. Degree centralization indicates the } \\
\text { dependence of the network on one or a small number of actors. } \\
\text { Reciprocity shows the share of ties (dyads) in the network that are } \\
\text { "confirmed" between two actors. Transitivity displays the degree of } \\
\text { ordered triples in which i-->j and j-->k. All network measurements were } \\
\text { calculated using dichotomized data. Before calculating network } \\
\text { centralization, the data were symmetrized. }\end{array}$} \\
\hline
\end{tabular}

The interactions between structural and actor policy preferences are shown in Table 5 where the core-periphery analysis of the policy network structure is combined with a systematization of the actors' policy preferences regarding the reduction of domestic support for agricultural products, the deregulation of international agricultural markets and the support of a further greening of the agricultural sector. For the preferences regarding the domestic support of Swiss agriculture and its potential further deregulation, the analysis reveals a strong cleavage between supporters and opponents of the AP 2011 reform. The supporting actors include the majority of the legislative and executive branches of the Swiss government, all governmental agencies, and trade associations. The opponents consist of the Swiss Farmers' Association (SBV) and the main political right-wing party SVP; the SVP has strong traditional ties with farmers and acts, together with the SBV, as their main political advocate. Regarding the issues of domestic support and international deregulation, the supportive actors are found in the core of the policy network, whereas opponents are located at the periphery. However, due to its organizational capacity and the generally high reputational power (displayed by the size of the actors in Fig. 2), we expect the opponents to in fact have a stronger political influence than what emanates from our network data. In addition, it has to be assumed that informal contacts between the network actors will also impact the policy process. These informal contacts, however, are not displayed by our data.

For the issue of greening, our results reveal a different picture. Again, the legislative and executive branches of government and all government agencies are supportive with regard to this issue. But unlike the other two issues, strong opposition arises only from the political party SVP. The SBV has an ambivalent opinion towards greening, meaning that its policy preferences are neither clearly supportive nor opposing. This ambivalence can be explained by the SBV's preference for a key core policy that maintains the income level of farmers and sustains the agricultural sector, at least in its current economic size. Hence, the SBV supports a greening scenario if it results in maintaining or even expanding direct payments for the agricultural sector, but opposes it if the consequences would mean a complete switch from production-oriented to a purely ecologically based direct payment system. However, the SBV could also be forced to support at least some elements of a greening scenario if ecologically oriented interests successfully form an alliance with liberal and left-wing political parties. Such an alliance would pose a credible threat due its veto power at the national political level, even though individual members of such a "green" alliance are rather peripheral actors in the agricultural policy network.

Table 5. Policy positions of core actors. $\dagger$

\begin{tabular}{lccc}
\hline \hline & $\begin{array}{c}\text { Reduction of } \\
\text { domestic support } \\
\text { for agricultural } \\
\text { products }\end{array}$ & $\begin{array}{c}\text { Deregulation of } \\
\text { international } \\
\text { agricultural } \\
\text { market }\end{array}$ & $\begin{array}{c}\text { Greening } \\
\text { of agricultural } \\
\text { sector }\end{array}$ \\
\hline $\begin{array}{l}\text { Strong } \\
\text { support } \\
\text { Moderate } \\
\text { support }\end{array}$ & TRA, FOA, FDEA, & FC, FOA, FDEA, & FC, FOA, FDEA, \\
$\begin{array}{l}\text { Indifferent } \\
\text { Moderate } \\
\text { opposition }\end{array}$ & CS, PNC & CS, PNC & CS, PNS \\
$\begin{array}{l}\text { Strong } \\
\text { opposition }\end{array}$ & SBV, SVP & SBV, SVP & SRA \\
\hline $\begin{array}{l}\dagger \text { Core/periphery model (CORR algorithm) according to Borgatti and } \\
\text { Everett (1999) and based on a value directed graph. Policy positions } \\
\text { based on overall scores in Appendices 2, 3, and 4. }\end{array}$ &
\end{tabular}

Given the structure of the current Swiss agricultural policy network and the policy preferences of the network actors, which of the three policy scenario seems most politically feasible and, thus, most likely?

\section{Scenario 1: status quo}

The status-quo scenario seems very likely given the current structure of the policy network and the alignment of the policy preferences in the sector. Further steps towards a significant decrease in public support for the agricultural sector will most probably face strong opposition from the agricultural sector itself, which would be politically supported by the SVP. Given the strong mobilizing power of the most important actors opposing such steps (SBV and SVP), it seems rather unlikely that the supporters of such a step will take the risk of a tooambitious reform proposal. Furthermore, we expect the actors opposing a further liberalization and greening to be able to actively mobilize resources to protect the status quo against challengers. However, given the strong and relatively stable policy preferences of the actors on the relevant issues, neither can we expect an opposite trend towards a significant 
extension of public support for the agricultural sector. Rather, given the policy preferences of the relevant actors and their current position in the policy network, we expect a continuation of public support for the agricultural sector at current levels. Such a continuation could involve active attempts to punctually weaken some recent reforms during the implementation stage as well as policy adjustments to preserve the status quo against current and future technological or socioeconomic developments (Baumgartner et al. 2009:247-250). Overall, the current policy network structure and the alignment of the policy preferences in the sector comply with the conditions necessary to maintain the status quo.

\section{Scenario 2: liberalization}

The liberalization scenario seems rather unlikely. The argumentation here is very much in line with the one regarding the status quo scenario. Both the structure of the network and the policy preferences of the relevant actors indicate a centerperiphery cleavage, with the SBV and the SVP currently being in a position to successfully veto further liberalization attempts. Again, since core aspects of the actors' policy preferences are concerned, changes in the policy preferences of these actors with significant political power cannot be expected in the nearer future. Quite the contrary, it seems possible that policy reforms that were decided during the formulation of the previous agricultural reform could even be weakened during the implementation stage of the reform and/ or that some reforms could even be reversed through future legislative acts. Given the current policy network structure, it can only be assumed that a major recomposition of the agricultural policy network, for example due to important developments at the broader national or international political level and/or through the entering of new and powerful political actors into the agricultural policy network, will lead to a major policy change towards an economic liberalization of the agricultural sector.

\section{Scenario 3: greening}

With respect to the scenario of a further greening of the agricultural sector, the analysis reveals neither a strong coreperiphery cleavage nor a significant cleavage among the key actors (with the exception of the SVP on the political right wing). Given the greening's mainly instrumental function for the main part of the agricultural sector itself, it seems realistic that the issue will stay on the political agenda as a (probably even more) central issue in future agricultural reforms. As illustrated by the position of the SBV, the agricultural sector seems, overall, to be willing to back this process as long the production-oriented support for the farmers does not get abolished entirely, and the economic level and significance of the agricultural sector can at least be maintained. However, given the opposition of the SBV towards a complete abolishment of production-oriented public support, a complete shift towards an entirely ecologically oriented direct payment scheme seems unlikely.

\section{DISCUSSION}

Our policy network analysis has shown how the central actors in the Swiss agricultural policy subsystem were able to use their political power resulting from shared policy preferences and closely coordinated political interactions to push the main parts of the AP 2011 reform through parliament. Even though the indicators for network closure revealed ambivalent results, the policy network still incorporates characteristics of a "policy community" (Smith 1990, Coleman et al. 1996) consisting of close and stable memberships, which typically includes the main responsible government ministry or agency in the policy subsystem and a few privileged producer groups and their interest organizations. Policy communities share an ideology about how major policy issues in the sector should be addressed. Across Europe, agricultural policy communities had used their political power to impede policy reforms towards a more market-oriented and sustainable development of the sector (Carter 2007:188).

As in other countries, however, the dominant policy community in the Swiss agricultural sector had been weakened by the major agricultural reforms of the 1990s, as our network indicators clearly indicate; it is today more dependent on political alliances than in the late 1980s and early 1990s (Sciarini 1994). But still, as our network analysis shows, a status-quo scenario seems to be the most likely development. The actors' preferences with regard to the main agricultural policy issues are currently relatively stable, which is why major transformations of the Swiss agricultural sector cannot be expected in the nearer future.

In contrast, a liberalization scenario appears very unlikely given the current policy network structure and the policy preferences of the key actors in the network, even though the reduction of financial transfers from consumers (and taxpayers) to farmers would be considerable. But the realization of the scenario would require a major policy change, which would face the strong opposition of the sector's main interest organizations. Such a change seems politically realistic only in combination with major political pressure from other economically powerful sectors and/or broader national or international political developments (as seen with the major agricultural reforms in Switzerland in the early 1990s, see Sciarini 1994), or due to major political and/or economic crises (Swinnen 2009). Accordingly, a stronger liberalization of the agricultural sector (if politically desirable) would probably have to be integrated in a wider policy framework with issue linkages to other policy sectors, e.g., as a consequence of a deeper Swiss integration into European Union policies, or in the context of the World Trade Organization. However, such policy linkages would result in a conflictive domestic negotiation process within and between policy sectors (Coleman et al. 1996, Sciarini and Nicolet 2005) and would have a highly uncertain outcome. 
The results from the model-based assessment of ecosystem goods and services provision in mountain regions support the likelihoods of the scenarios as found in the policy network analysis. As with many others model-based assessments of ecosystem services (e.g., Rodriguez et al. 2006, Groot et al. 2007, Waldhardt et al. 2010, Helming et al. 2011), our findings reveal trade-offs between marketable and nonmarketable ecosystem goods and services inherent to the agricultural production process (Abler 2004). In addition, natural conditions and the initial farm structures result in different levels of provision of ecosystem goods and services, as seen in the analysis of the two case study regions as well as in other studies of European mountain regions (Hanley et al. 2012, Flury et al. 2013). No scenario fulfills all the policy goals formulated by the federal public administration. As a consequence, policy changes that alter current production incentives (liberalization, greening) would reduce the provision of one of the modeled ecosystem goods and services, at least in one of the studied regions.

Hence, even though the greening scenario could become a more realistic scenario in the future according to the network analysis, the resulting reduction in the production level would probably still provoke opposition from the sector's main interest organization, the Swiss Farmers' Association (SBV). The conservative political right wing would most certainly not accept a scenario that leads to large-scale reductions in agricultural production (Huber et al. 2011). However, our findings also indicate that policy measures that would support an increase of nonmarketable ecosystem goods and services in mountain regions may not be supported in the political process either because their impact does not generally increase the provision of all ecosystem goods and services within the different regions. In addition, the combination of different policy instruments in one policy scenario revealed the importance of a concomitant consideration of the different effects. In the greening scenario, the reduction in market access resulted in a considerable decrease of agricultural production, which, in turn, would reduce the likelihood of the scenarioeven if payments for environmental services would find acceptance in the political process.

Methodologically, our study has demonstrated how a policy network approach provides a useful way to assess the feasibility and likelihood of policy developments as they can be derived from scenario-based ex-ante assessments using economic models. In addition to previous studies (Selin and VanDeveer 2007), we have extended the qualitative scenario storylines with predictions of ecosystem goods and services in mountain regions based on an integrative modeling approach. We are aware that the results of model-based scenario assessments are associated with uncertainty (Fischer et al. 2007) and may change considerably if underlying parameters and assumptions are adjusted (Sterman 1991). Sensitivity analysis and a more integrated assessment (e.g.,
Van Ittersum and Brouwer 2009), optionally combined with closer stakeholder involvement (e.g., Brand et al. 2013), may increase the accuracy of the future provision of ecosystem services. But more fundamentally, the policy network taken into consideration in our study was not just assumed but measured empirically. This allowed us to conceptually include political variables into our assessment of possible future developments of Swiss agricultural policy. Empirically, the network characteristics provide-in combination with a categorization of the policy preferences-a more accurate and realistic picture of actual political processes than in previous model-based ex-ante assessments.

\section{CONCLUSION}

The analysis of potential agricultural policy developments based on a policy network study shows that a productionoriented agricultural policy still has strong political supportdespite potential negative ecological and economic effects. Furthermore, the proponents of the policy have the capacity to preserve the status quo, even though they might be forced occasionally to make punctual concessions to oppositional actors that demand a more ecological and stronger freemarket-oriented policy. Major attempts to fundamentally challenge the current policy, however, would most certainly mobilize the defenders of the status quo, who are in a strategically favorable position to also effectively defend it. Given this political constellation, a status-quo scenario seems therefore very likely. A scenario of greening could provide a politically realistic alternative given the policy preferences of the main political actors in the current agricultural policy network if the proponents of a greening scenario succeed in getting the main political representative of the sector (organized in the Swiss Farmers' Association) on board. This seems politically realistic if a more ecologically oriented direct payment scheme would guarantee compensation for decreased product-oriented support and agricultural production would not be reduced dramatically. However, our model-based assessment shows-at least for mountain regions-that agricultural production would decrease considerably in a greening scenario, which, again, increases the likeliness of a status-quo scenario. Thus, if politically desired, the implementation of more environmentally friendly agricultural policy measures has to reconcile the support of the provision of nonmarketable ecosystem goods and services with concomitant policy changes (such as market deregulation) which directly affect the level of agricultural production.

The combination of a policy network approach with an exante policy assessment model proved suitable and revealed the importance of concomitant policy measures in the implementation of policy instruments that potentially increase the provision of ecosystem goods and services in mountain regions. It allowed us to systematically include political variables into the assessment of possible future developments of Swiss agricultural policy and, thus, to overcome one of the 
major inaccuracies of ex-ante policy assessments: the neglect or misrepresentation of the underlying political structures. Nevertheless, some limitations of our approach should be mentioned too. Despite the systematic analysis in the individual parts of our conceptual framework (ex-ante optimization model, policy network analysis, analysis of the actors' policy preferences as well as the consideration of organizational and institutional characteristics), the links between these analytical components are based on mainly qualitative descriptions of the underlying mechanisms. Even though such a qualitative approach is common practice in scenario analysis (Garb et al. 2008, Pulver and VanDeveer 2009), these connections would need more scrutiny in order to be able to examine causal relationships (Gerring 2010, Glynn and Quinn 2011). A further step in the linkage between the policy making process on the one hand and economic and ecological impacts on the other hand could include the insights from the policy network analysis directly in the ex-ante modelbased assessment using quantified network measures. This, however, would ask for a different modeling approach, such as genetic algorithms that are able to systematically consider different combinations of policy alternatives instead of conventional scenario analysis.

Responses to this article can be read online at: http://www.ecologyandsociety.org/issues/responses. php/5480

\section{Acknowledgments:}

The study was supported by the Competence Center Environment and Sustainability (CCES) of the ETH Domain, Switzerland, as part of the research project MOUNTLAND. We are grateful to the editor in chief of Ecology and Society, the subject editor, and two anonymous reviewers for their helpful comments.

\section{LITERATURE CITED}

Abildtrup, J., E. Audsley, M. Fekete-Farkas, C. Giupponi, M. Gylling, P. Rosato, and M. Rounsevell. 2006. Socio-economic scenario development for the assessment of climate change impacts on agricultural land use: a pairwise comparison approach. Environmental Science \& Policy 9:101-115. http:// dx.doi.org/10.1016/j.envsci.2005.11.002

Abler, D. 2004. Multifunctionality, agricultural policy, and environmental policy. Agriculture and Resource Economics Review 33:8-18.

Adam, S., and H. Kriesi. 2007. The network approach. Pages 129-154 in P. A. Sabatier, editor. Theories of the policy process. Westview Press, Boulder, Colorado, USA. http://dx. doi.org/10.1016/0960-1481(96)00066-3
Anderson, K. 2010. The political economy of agricultural price distortions. Cambridge University Press, Cambridge, UK. http://dx.doi.org/10.1017/CBO9780511778964

Bare, J. 2011. Recommendation for land use impact assessment: first steps into framework, theory, and implementation. Clean Technologies and Environmental Policy 13:7-18. http://dx.doi.org/10.1007/s10098-010-0290-8

Baumgartner, F. R., J. M. Berry, M. Hojnacki, D. C. Kimball, and B. L. Leech. 2009. Lobbying and policy change: who wins, who loses, and why. University of Chicago Press, Chicago, Illinois, USA. http://dx.doi.org/10.7208/chicago/9780226039466.001.0001

Bezlepkina, I., P. Reidsma, S. Sieber, and K. Helming. 2010. Integrated assessment of sustainability of agricultural systems and land use: methods, tools and applications. Agricultural Systems 104:105-109. http://dx.doi.org/10.1016/j.agsy.2010.11.002

Borgatti, S. P., and M. G. Everett. 1999. Models of core/ periphery structures. Social Networks 21:375-395. http://dx. doi.org/10.1016/S0378-8733(99)00019-2

Borgatti, S. P., M. G. Everett, and L. C. Freeman. 2002. Ucinet for Windows: software for social network analysis. Analytic Technologies, Harvard, Massachusetts, USA.

Borgatti, S. P., and D. S. Halgin. 2011. Analyzing affiliation networks. Pages 417-433 in J. Scott and P. J. Carrington, editors. The SAGE Handbook of social network analysis. Sage, Los Angeles, California, USA.

Brand, F. S., R. Seidl, Q. B. Le, J. M. Brändle, and R. W. Scholz. 2013. Constructing consistent multiscale scenarios by transdisciplinary processes: the case of mountain regions facing global change. Ecology and Society 18(2): 43. http:// dx.doi.org/10.5751/ES-04972-180243

Briner, S., R. Huber, C. Elkin, and A. Grêt-Regamey. 2012. Assessing the impacts of economic and climate changes on land-use in mountain regions: a spatial dynamic modeling approach. Agriculture, Ecosystems \& Environment 149:50-63. http://dx.doi.org/10.1016/j.agee.2011.12.011

Carter, N. 2007. The politics of the environment: ideas, activism, policy. 2nd edition. Cambridge University Press, Cambridge, UK.

Coleman, W. d., G. D. Skogstad, and M. M. Atkinson. 1996. Paradigm shifts and policy networks: cumulative change in agriculture. Journal of Public Policy 16:273-301. http://dx. doi.org/10.1017/S0143814X00007777

Daugbjerg, C. 1997. Policy networks and agricultural policy reforms: explaining deregulation in Sweden and re-regulation in the European Community. Governance 10:123-142. http:// dx.doi.org/10.1111/0952-1895.341997034 
Daugbjerg, C. 1998. Linking policy networks and environmental policies: nitrate policy making in Denmark and Sweden 1970-1995. Public Administration 76:275-294. http:// dx.doi.org/10.1111/1467-9299.00101

Davies, H. T. O., S. M. Nutley, and P. C. Smith. 2000. What works? Evidence-based policy and practice in public services. The Policy Press, Bristol, UK. http://dx.doi.org/10.1332/ policypress/9781861341914.001.0001

De Gorter, H., and J. Swinnen. 2002. Chapter 36: political economy of agricultural policy. Pages 1893-1943 in B. L. Gardner and G. C. Rausser, editors. Handbook of Agricultural Economics. Edition 1, volume 2, number 4, part 2. Elsevier, Netherlands. http://dx.doi.org/10.1016/S0079-6417(08)60108-0

De Smedt, P. 2011. The use of impact assessment tools to support sustainable policy objectives in Europe. Ecology and Society 15(4):30. [online] URL: http://www.ecologyandsociety. org/vol15/iss4/art30.

Dilly, O., and D. J. Pannell. 2009. Sustainability impact assessment and land-use policies for sensitive regions. Environmental Science \& Policy 12:1075-1076. http://dx.doi. org/10.1016/j.envsci.2009.09.004

European Commission. 2004. Mountain areas in Europe: analysis of mountain areas in EU member states, acceding and other European countries. European Commission, Brussels, Belgium.

Fischer, A. 2003. Vetospieler und die Durchsetzbarkeit von Side-Payments: Der schweizerische innenpolitische Entscheidungsprozess um flankierende Massnahmen zur Personenfreizügigkeit mit der Europäischen Union. Swiss Political Science Review 9:27-58. http://dx.doi.org/10.1002/ j.1662-6370.2003.tb00412.x

Fischer, A., L. Petersen, C. Feldkötter, and W. Huppert. 2007. Sustainable governance of natural resources and institutional change: an analytical framework. Public Administration and Development 27:123-137. http://dx.doi.org/10.1002/pad.442

Fischer, M., A. Fischer, and P. Sciarini. 2009. Power and conflict in the Swiss political elite: an aggregation of existing network analyses. Swiss Political Science Review 15:31-62. http://dx.doi.org/10.1002/j.1662-6370.2009.tb00122.x

Flury, C., R. Huber, and E. Tasser. 2013. The future of mountain agriculture in the Alps. Pages 105-126 in S. Mann, editor. The future of mountain agriculture. Springer, Berlin, Germany. http://dx.doi.org/10.1007/978-3-642-33584-6 8

FOAG and FOEN. 2008. Umweltziele Landwirtschaft: Hergeleitet aus bestehenden rechtlichen Grundlagen [Environmental goals agriculture: Derived from the existing legal basis]. Federal Office for Agriculture (FOAG) and Federal Office for the Environment (FOEN), Bern, Switzerland.
Garb, Y., S. Pulver, and S. D. VanDeveer. 2008. Scenarios in society, society in scenarios: toward a social scientific analysis of story-driven environmental modeling. Environmental Research Letters 3:045015.

Gerring, J. 2010. Causal Mechanisms: Yes, but... Comparative Political Studies 43:1499-1526. http://dx.doi.org/10.1177/0010414010376911

Glynn, A. N., and K. M. Quinn. 2011. Why process matters for causal inference. Political Analysis 19:273-286. http://dx. doi.org/10.1093/pan/mpr021

Grêt-Regamey, A., A. Walz, and P. Bebi. 2008. Valuing ecosystem services for sustainable landscape planning in alpine regions. Mountain Research and Development 28:156-165. http://dx.doi.org/10.1659/mrd.0951

Groot, J. C. J., W. A. H. Rossing, A. Jellema, D. J. Stobbelaar, H. Renting, and M. K. Van Ittersum. 2007. Exploring multiscale trade-offs between nature conservation, agricultural profits and landscape quality - a methodology to support discussions on land-use perspectives. Agriculture, Ecosystems \& Environment 120:58-69.

Hanley, N., S. Acs, M. Dallimer, K. J. Gaston, A. Graves, J. Morris, and P. R. Armsworth. 2012. Farm-scale ecological and economic impacts of agricultural change in the uplands. Land Use Policy 29:587-597. http://dx.doi.org/10.1016/j. landusepol.2011.10.001

Helming, K., K. Diehl, T. Kuhlman, T. Jansson, P. H. Verburg, M. Bakker, M. Perez-Soba, L. Jones, P. J. Verkerk, P. Tabbush, J. Breton Morris, Z. Drillet, J. Farrington, P. LeMouël, P. Zagame, T. Stuczynski, G. Siebielec, S. Sieber, and H. Wiggering. 2011. Ex ante impact assessment of policies affecting land use, part B: application of the analytical framework. Ecology and Society 16(1):29. [online] URL: http://www.ecologyandsociety.org/vol16/iss1/art29/.

Helming, K., and M. Pérez-Soba. 2011. Landscape scenarios and multifunctionality: making land use impact assessment operational. Ecology and Society 16(1):50. [online] URL: http://www.ecologyandsociety.org/vol16/iss 1/art50/.

Henry, A. D. 2011. Ideology, power, and the structure of policy networks. Policy Studies Journal 39:361-383. http://dx.doi. org/10.1111/j.1541-0072.2011.00413.x

Hertin, J., J. Turnpenny, A. Jordan, M. Nilsson, D. Russel, and B. Nykvist. 2009. Rationalising the policy mess? Ex ante policy assessments and the utilisation of knowledge in the policy process. Environment and Planning A 41:1185-1200. http://dx.doi.org/10.1068/a40266

Hirschi, C. 2010. Strengthening regional cohesion: collaborative networks and sustainable development in Swiss rural areas. Ecology and Society 15(4):16. [online] URL: http://www.ecologyandsociety.org/vol15/iss4/art16/. 
Huber, R., A. Rigling, P. Bebi, F. S. Brand, S. Briner, A. Buttler, C. Elkin, F. Gillet, A. Grêt-Regamey, C. Hirschi, H. Lischke, R. W. Scholz, R. Seidl, T. Spiegelberger, A. Walz, W. Zimmermann, and H. Bugmann. 2013a. Sustainable land use in mountain regions under global change: synthesis across scales and disciplines. Ecology and Society 18(3) in press.

Huber, R., S. Briner, A. Peringer, S. Lauber, R. Seidl, A. Widmer, F. Gillet, A. Buttler, Q. Bao Le, and C. Hirschi. 2013b. Modeling social-ecological feedback effects in the implementation of payments for environmental services in pasture-woodlands. Ecology and Society 18(2): 41. http://dx. doi.org/10.5751/ES-05487-180241

Huber, R., H. Bugmann, A. B. Buttler, and A. Rigling. $2013 c$. Sustainable land-use practices in European mountain regions under global change: an integrated research approach. Ecology and Society $18(3)$ in press.

Huber, R., M. Hunziker, and B. Lehmmann. 2011. Valuation of agricultural land-use scenarios with choice experiments: a political market share approach. Journal of Environmental Planning and Management 54:93-113. http://dx.doi. org/10.1080/09640568.2010.502761

Huber, U. M., H. K. M. Bugmann, and M. A. Reasoner, editors. 2005. Global change and mountain regions: overview of current knowledge. Springer, Dordrecht, The Netherlands.

Immergut, E. M. 1992. The rules of the game: The logic of health policy-making in France, Switzerland, and Sweden. Pages 57-89 in S. Steinmo, K. Thelen, and F. Longstreth, editors. Structuring politics: historical institutionalism in comparative analysis. Cambridge University Press, Cambridge, UK. http://dx.doi.org/10.1017/CB09780511528125.004

Imperial, M. T. 1999. Institutional analysis and ecosystembased management: the institutional analysis and development framework. Environmental Management 24:449-465. http:// dx.doi.org/10.1007/s002679900246

IPCC. 2000. IPCC special report emissions scenarios. Intergovernmental Panel on Climate Change (IPCC), Geneva, Switzerland.

IPCC. 2001. Special report on the regional impacts of climate change: an assessment of vulnerability. Intergovernmental Panel on Climate Change (IPCC), Geneva, Switzerland.

Jokinen, P. 1997. Agricultural policy community and the challenge of greening: the case of Finnish agri-environmental policy. Environmental Politics 6:48-71. http://dx.doi. org/10.1080/09644019708414327

Jones, B. D. 1999. Bounded rationality. Annual Review of Political Science 2:297-321. http://dx.doi.org/10.1146/ annurev.polisci.2.1.297
Jones, B. D. 2003. Bounded rationality and political science: lessons from public administration and public policy. Journal of Public Administration Research and Theory 13:394-412. http://dx.doi.org/10.1093/jopart/mug028

Knoke, D. 1990. Political networks: the structural perspective. Cambridge University Press, Cambridge, UK. http://dx.doi.org/10.1017/CBO9780511527548

Knoke, D. 2011. Policy networks. Pages 210-222 in J. Scott and P. Carrington, editors. The Sage handbook of social network analysis. Sage, London, UK. http://dx.doi. org/10.1017/CBO9781139174497

Kok, K., and T. A. Veldkamp. 2011. Scale and governance: conceptual considerations and practical implications. Ecology and Society 16(2):23. [online] URL: http://www. ecologyandsociety.org/vol16/iss2/art23/main.html.

Kriesi, H., S. Adam, and M. Jochum. 2006. Comparative analysis of policy networks in western Europe. Journal of European Public Policy 13:341-361. http://dx.doi. org/10.1080/13501760500528803

Laumann, E. O., and D. Knoke. 1987. The organizational state: social choice in national policy domains. University of Wisconsin Press, Madison, Wisconsin, USA.

Laver, M. 2001. Why should we estimate the policy positions of political actors? Pages 3-9 in M. Laver, editor. Estimating the policy positions of political actors. Routledge, London, UK.

Nilsson, M., A. Jordan, J. Turnpenny, J. Hertin, B. Nykvist, and D. Russel. 2008. The use and non-use of policy appraisal tools in public policy making: an analysis of three European countries and the European Union. Policy Sciences 41:335-355. http://dx.doi.org/10.1007/s11077-008-9071-1

Pulver, S., and S. D. VanDeveer. 2009. 'Thinking about tomorrows': scenarios, global environmental politics, and social science scholarship. Global Environmental Politics 9:1-13. http://dx.doi.org/10.1162/glep.2009.9.2.1

Rausser, G. C. and R. E. Goodhue. 2002. Chapter 39: public policy: its many analytical dimensions. Pages 2057-2102 in B. L. Gardner and G. C. Rausser, editors. Handbook of agricultural economics. Edition 1, volume 2, number 4, part 2. Elsevier, Netherlands.

Rausser, G. C., and J. Swinnen. 2011. Governance structures, political economy and public policy. American Journal of Agricultural Economics 93:310-316.

Rhodes, R. A. W. 1997. Understanding governance: policy networks, governance, reflexivity, and accountability. Open University Press, Buckingham, UK.

Rodriguez, J. P., T. D. J. Beard, E. M. Bennett, G. S. Cumming, S. J. Cork, J. Agard, A. P. Dobson, and G. D. Peterson. 2006. 
Trade-offs across space, time, and ecosystem services. Ecology and Society 11(1):28. [online] URL: http://www. ecologyandsociety.org/vol11/iss1/art28/.

Sabatier, P. A. and H. C. Jenkins-Smith. 1993. Policy change and learning: an advocacy coalition approach. Westview Press, Boulder, Colorado, USA.

Sanderson, I. 2002. Evaluation, policy learning and evidencebased policy making. Public Administration 80:1-22. http:// dx.doi.org/10.1111/1467-9299.00292

Sciarini, P. 1994. La Suisse face à la Communauté Euopéenne et au GATT: Le cas test de la politique agricole. Editions Georg, Genève, La Suisse.

Sciarini, P., and S. Nicolet. 2005. Internationalization and domestic politics: evidence from the Swiss case. Pages 221-238 in H. Kriesi, P. Farago, M. Kohli, and M. ZarinNejadan, editors. Contemporary Switzerland: revisiting the special case. Palgrave Macmillan, Basingstoke, UK.

Selin, H., and S. D. VanDeveer. 2007. Political science and prediction: what's next for U.S. climate policy? Review of Policy Research 24:1-27. http://dx.doi.org/10.1111/ j.1541-1338.2007.00265.x

Serdült, U. and C. Hirschi. 2004. From process to structure: developing a reliable and valid tool for policy network comparison. Swiss Political Science Review 10:137-155. http://dx.doi.org/10.1002/j.1662-6370.2004.tb00026.x

Smith, M. J. 1990. The politics of agricultural support in Britain: the development of an agricultural policy community. Dartmouth, London, UK.

Sterman, J. D. 1991. A skeptic's guide to computer models. Pages 1-25 in G. O. Barney, W. B. Kreutzer, and M. Garrett, J., editors. Managing a nation: the microcomputer software catalog. Westview Press, Boulder, Colorado, USA.

Stucki, E. W., O. Roque, M. Schuler, and M. Perlink. 2004. Contents and impacts of mountain policies Switzerland: national report for the study on "Analysis of mountain areas in the European Union and in the applicant countries" (Report commissioned by the SECO, Federal Department of Economic Affairs). State Secretariat for Economic Affairs, Federal Department of Economic Affairs, Bern, Switzerland.

Swimmen, J., and F. A. Van der Zee. 1993. The political economy of agricultural policies: a survey. European Review of Agricultural Economics 20:261-290. http://dx.doi. org/10.1093/erae/20.3.261

Swinnen, J. F. M. 2009. The growth of agricultural protection in Europe in the 19th and 20th centuries. World Economy 32:1499-1537. http://dx.doi.org/10.1111/j.1467-9701.2009.01247.
Van Ittersum, M. K., and F. Brouwer. 2009. Integrated assessment of agricultural and environmental policiesconcepts and tools. Environmental Science \& Policy 12:543-545.

Veldkamp, A., and E. F. Lambin. 2001. Predicting land-use change. Agriculture, Ecosystems \& Environment 85:1-6. http://dx.doi.org/10.1016/S0167-8809(01)00199-2

Verburg, P. H., D. B. van Berkel, A. M. van Doorn, M. van Eupen, and H. A. R. M. van den Heiligenberg. 2010. Trajectories of land use change in Europe: a model-based exploration of rural futures. Landscape Ecology 25:217-232. http://dx.doi.org/10.1007/s10980-009-9347-7

Waldhardt, R., M. Bach, R. Borresch, L. Breuer, T. Dietkötter, H.-G. Frede, S. Gäth, O. Ginzler, T. Gottschalk, S. Julich, M. Krumpholz, F. Kuhlmann, A. Otte, B. Reger, W. Reiher, K. Schmitz, P. M. Schmitz, P. Sheridan, D. Simmering, C. Weist, V. Wolters, and D. Zörner. 2010. Evaluating today's landscape multifunctionality and providing an alternative future: a normative scenario approach. Ecology and Society 15(3):30. [online] URL: http://www.ecologyandsociety.org/vol15/iss3/ art30\%.

Wasserman, S., and K. Faust. 1994. Social network analysis: methods and applications. Cambridge University Press, Cambridge, UK. http://dx.doi.org/10.1017/CBO9780511815478

Westhoek, H. J., M. van den Berg, and J. A. Bakkes. 2006. Scenario development to explore the future of Europe's rural areas. Agriculture, Ecosystems \& Environment 114:7-20. http://dx.doi.org/10.1016/j.agee.2005.11.005

Widmer, T., C. Hirschi, U. Serdült, and C. Vögeli. 2008. Analysis with APES, the actor process event scheme. Pages 150-171 in M. M. Bergmann, editor. Advances in mixed methods research: theories and applications. Sage, Los Angeles, California, USA.

Wittrock, B., and P. de Leon. 1986. Policy as a moving target: a call for conceptual realism. Review of Policy Research 6:44-60. http://dx.doi.org/10.1111/j.1541-1338.1986.tb00646. $\underline{x}$

Young, O. R. 2002. The institutional dimensions of environmental change: fit, interplay, and scale. MIT Press, Cambridge, Massachusetts, USA.

Young, O. R., L. A. King, and H. Schroeder, editors. 2008. Institutions and environmental change: principal findings, applications, and research frontiers. MIT Press, Cambridge, Massachusetts, USA. 


\section{Appendix 1: Actor list}

\begin{tabular}{ll}
\hline \hline Acronym & Actor \\
\hline ANI & Animal Protection Organizations \\
ASS & Other Professional Associations \\
CAN & Cantons \\
COM & Referendum Committee \\
CON & Consumer Organizations \\
CS & Council of States \\
CVP & Christian Democratic Party \\
DEL & Swiss Delegation WTO Negotiations \\
ECO & Economiesuisse \\
ENV & Environmental and Development Organizations \\
FC & Swiss Federal Council \\
FD & Finance Delegation NC-CS \\
FDEA & Federal Department of Economic Affairs \\
FDJP & Federal Department of Justice and Police \\
FDP & Free Democratic Party \\
FOA & Federal Office of Agriculture \\
GRE & Green Party \\
KBV & Cantonal Farmers' Associations \\
NC & National Council \\
OTH & Other Associations or Organizations \\
PAR & Other Political Parties \\
PCS & Parliamentary Committee for Economic Affairs and Taxation CS \\
PNC & Parliamentary Committee for Economic Affairs and Taxation NC \\
SAB & Swiss Association for Mountain Regions \\
SBV & Swiss Farmers' Association \\
SPS & Social Democratic Party \\
SVP & Swiss People's Party \\
TRA & Trade Associations \\
UNI & Trade Unions \\
\hline
\end{tabular}




\section{Appendix 2: Actor policy preferences on decreasing domestic support for agricultural products}

\begin{tabular}{|c|c|c|c|c|c|}
\hline \multirow[b]{2}{*}{ Actor } & \multicolumn{5}{|c|}{ Support for the reduction of public support for agricultural products } \\
\hline & Dairy & Meat & Fruits/Veg. & Grain & Overall \\
\hline ANI & 0 & 0 & 0 & 0 & 0.00 \\
\hline ASS & 0 & 0 & 0 & 0 & 0.00 \\
\hline CAN & -1 & 1 & -2 & -1 & -0.75 \\
\hline $\mathrm{CON}$ & 1 & 1 & 1 & 1 & 1.00 \\
\hline $\mathrm{CS}$ & -1 & 1 & 1 & 1 & 0.50 \\
\hline CVP & 1 & -1 & -1 & -1 & -0.50 \\
\hline DEL & 1 & 1 & 1 & 1 & 1.00 \\
\hline ECO & 1 & 1 & 1 & 1 & 1.00 \\
\hline ENV & 1 & 1 & 1 & 1 & 1.00 \\
\hline $\mathrm{FC}$ & 1 & 1 & 1 & 1 & 1.00 \\
\hline FD & 0 & 0 & 0 & 0 & 0.00 \\
\hline FDEA & 1 & 1 & 1 & 1 & 1.00 \\
\hline FDJP & 0 & 0 & 0 & 0 & 0.00 \\
\hline FDP & 2 & 2 & 2 & 2 & 2.00 \\
\hline FOA & 1 & 1 & 1 & 1 & 1.00 \\
\hline GRE & 1 & 1 & 1 & 1 & 1.00 \\
\hline KBV & -2 & -2 & -1 & -1 & -1.50 \\
\hline $\mathrm{NC}$ & -1 & 1 & 1 & 1 & 0.50 \\
\hline OTH & 0 & 0 & 0 & 0 & 0.00 \\
\hline PAR & 0 & 0 & 0 & 0 & 0.00 \\
\hline PCS & -1 & 1 & 1 & 1 & 0.50 \\
\hline PNS & -1 & 1 & 1 & 1 & 0.50 \\
\hline SAB & -2 & -2 & -2 & -2 & -2.00 \\
\hline SBV & -2 & -2 & -1 & -1 & -1.50 \\
\hline SPS & 1 & 1 & 1 & 1 & 1.00 \\
\hline SVP & -2 & -2 & -2 & -2 & -2.00 \\
\hline TRA & 2 & 2 & 2 & 2 & 2.00 \\
\hline UNI & -2 & -2 & -2 & -2 & -2.00 \\
\hline
\end{tabular}

Note: 2 = AP 2011 does not go far enough (strong support for reduction of domestic support for agricultural products); 1 = support for measures proposed in AP 2011 (moderate support for reduction of domestic support for agricultural products); $0=$ no/indifferent position; $-1=$ maintaining status quo (maintaining support level prior AP $2011=$ moderate opposition against reduction of domestic support for agricultural products); $-2=$ status quo prior AP 2011 already too low (strong opposition against reduction of public support for agricultural products or even claim for extension of public support). Overall $=$ mean value. 


\section{Appendix 3: Actor policy preferences on deregulating agricultural trade}

\begin{tabular}{|c|c|c|c|c|}
\hline Actor & $\begin{array}{r}\text { Reduction of } \\
\text { domestic export } \\
\text { support }\end{array}$ & $\begin{array}{r}\text { Reduction of } \\
\text { domestic market } \\
\text { support }\end{array}$ & $\begin{array}{r}\text { Reduction of } \\
\text { tariffs on } \\
\text { agricultural goods }\end{array}$ & $\begin{array}{l}\text { Overall } \\
\text { (mean) }\end{array}$ \\
\hline ANI & 0 & 0 & 0 & 0.00 \\
\hline ASS & 0 & 0 & 0 & 0.00 \\
\hline CAN & -1 & -1 & -1 & -1.00 \\
\hline $\mathrm{CON}$ & 1 & 1 & 1 & 1.00 \\
\hline $\mathrm{CS}$ & 1 & 1 & 1 & 1.00 \\
\hline CVP & -1 & 1 & 1 & 0.33 \\
\hline DEL & 2 & 1 & 1 & 1.33 \\
\hline ECO & 1 & 1 & 1 & 1.00 \\
\hline ENV & 1 & 1 & 1 & 1.00 \\
\hline $\mathrm{FC}$ & 2 & 1 & 1 & 1.33 \\
\hline FD & 0 & 0 & 0 & 0.00 \\
\hline FDEA & 2 & 1 & 1 & 1.33 \\
\hline FDJP & 0 & 0 & 0 & 0.00 \\
\hline FDP & 2 & 2 & 2 & 2.00 \\
\hline FOA & 2 & 1 & 1 & 1.33 \\
\hline GRE & 1 & 1 & 1 & 1.00 \\
\hline KBV & -2 & -2 & -2 & -2.00 \\
\hline $\mathrm{NC}$ & 1 & 1 & 1 & 1.00 \\
\hline OTH & 0 & 0 & 0 & 0.00 \\
\hline PAR & 0 & 0 & 0 & 0.00 \\
\hline PCS & 1 & 1 & 1 & 1.00 \\
\hline PNS & 1 & 1 & 1 & 1.00 \\
\hline SAB & -2 & -2 & -2 & -2.00 \\
\hline SBV & -2 & -2 & -2 & -2.00 \\
\hline SPS & 1 & 1 & 1 & 1.00 \\
\hline SVP & -2 & -2 & -2 & -2.00 \\
\hline TRA & 2 & 2 & 2 & 2.00 \\
\hline UNI & -2 & -2 & -2 & -2.00 \\
\hline
\end{tabular}

Note: Reduction of domestic export/market support: 2 = AP 2011 does not go far enough (strong support for reduction of domestic support); $1=$ support for measures proposed in AP 2011 (moderate support for reduction of domestic support); $0=$ no/indifferent position; $-1=$ maintaining status quo (maintaining support level prior AP $2011=$ moderate opposition against reduction of domestic support); -2 = status quo prior AP 2011 already too low (strong opposition against reduction of public support or even claim for extension of public support). Reduction of tariffs on agricultural goods: 2 = AP 2011 does not go far enough (strong support for better market access); 1 = support for measures proposed in AP 2011 (moderate support for better market access); 0 = no/indifferent position; -1 = contra AP 2011 proposal (moderate opposition against better market access); - 2 = status quo already overboard (strong opposition against better market access). Overall $=$ mean value . 


\section{Appendix 4: Actor policy preferences on greening the agricultural sector}

\begin{tabular}{|c|c|c|c|}
\hline Actor & $\begin{array}{r}\text { Increasing direct } \\
\text { payments for } \\
\text { ecological services }\end{array}$ & $\begin{array}{l}\text { Increasing eco- } \\
\text { standards for } \\
\text { agricultural products }\end{array}$ & $\begin{array}{c}\text { Overall } \\
\text { (mean) }\end{array}$ \\
\hline ANI & 2 & 2 & 2.00 \\
\hline ASS & 0 & 0 & 0.00 \\
\hline CAN & 1 & -1 & 0.00 \\
\hline $\mathrm{CON}$ & 0 & 2 & 1.00 \\
\hline CS & 1 & 0 & 0.50 \\
\hline CVP & 1 & 1 & 1.00 \\
\hline DEL & 1 & 1 & 1.00 \\
\hline ECO & 0 & -1 & -0.50 \\
\hline ENV & 2 & 2 & 2.00 \\
\hline $\mathrm{FC}$ & 1 & 1 & 1.00 \\
\hline FD & 0 & 0 & 0.00 \\
\hline FDEA & 1 & 1 & 1.00 \\
\hline FDJP & 0 & 0 & 0.00 \\
\hline FDP & 0 & 0 & 0.00 \\
\hline FOA & 1 & 1 & 1.00 \\
\hline GRE & 2 & 2 & 2.00 \\
\hline KBV & 1 & -1 & 0.00 \\
\hline $\mathrm{NC}$ & 1 & 0 & 0.50 \\
\hline OTH & 0 & 0 & 0.00 \\
\hline PAR & 0 & 0 & 0.00 \\
\hline PCS & 1 & 1 & 1.00 \\
\hline PNC & 1 & 1 & 1.00 \\
\hline SAB & 1 & 1 & 1.00 \\
\hline SBV & 1 & -1 & 0.00 \\
\hline SPS & 1 & 1 & 1.00 \\
\hline SVP & -2 & -2 & -2.00 \\
\hline TRA & 0 & 0 & 0.00 \\
\hline UNI & 1 & 1 & 1.00 \\
\hline
\end{tabular}

Note: 2 = AP does not go far enough (strong support for payments/standards or increase thereof); 1 = support for measures proposed in AP 2011 (moderate support for payments/standards or increase thereof); $0=$ no/indifferent position; $-1=$ maintaining status quo (moderate opposition against payments/standards or increase thereof); $-2=$ status quo prior AP 2011 already overboard (strong opposition against payments/standards or even claim for their decrease). Overall = mean value. 
Appendix 5: Organizational capacity and reputational power of non-state actors in the agricultural sector

\begin{tabular}{|c|c|c|c|}
\hline Actor & $\begin{array}{r}\text { Organizational } \\
\text { capacity }\end{array}$ & $\begin{array}{r}\text { Reputational } \\
\text { power }\end{array}$ & Overall score \\
\hline ANI & 1 & 0 & 2 \\
\hline ASS & 0 & 0 & 1 \\
\hline CAN & - & - & - \\
\hline $\mathrm{COM}$ & - & - & - \\
\hline $\mathrm{CON}$ & 0 & 0 & 1 \\
\hline $\mathrm{CS}$ & - & - & - \\
\hline CVP & 1 & 1 & 3 \\
\hline DEL & - & - & - \\
\hline $\mathrm{ECO}$ & 1 & 1 & 3 \\
\hline ENV & 1 & 0 & 2 \\
\hline $\mathrm{FC}$ & - & - & - \\
\hline FD & - & - & - \\
\hline FDEA & - & - & - \\
\hline FDJP & - & - & - \\
\hline FDP & 1 & 1 & 3 \\
\hline FOA & - & - & - \\
\hline GRE & 1 & 0 & 2 \\
\hline KBV & 1 & 0 & 2 \\
\hline $\mathrm{NC}$ & - & - & - \\
\hline OTH & - & - & - \\
\hline PAR & 0 & 0 & 1 \\
\hline PCS & - & - & - \\
\hline $\mathrm{PNC}$ & - & - & - \\
\hline SAB & 0 & 0 & 1 \\
\hline SBV & 1 & 0 & 2 \\
\hline SPS & 1 & 1 & 3 \\
\hline SVP & 1 & 1 & 3 \\
\hline TRA & 1 & 1 & 3 \\
\hline UNI & 0 & 0 & 1 \\
\hline
\end{tabular}

Note: Organizational capacity: As a facultative referendum in Switzerland demands the collection of 50,000 signatures within 100 days, organizations with more or equal then 100,000 members were coded 1, otherwise 0. Reputational power: Organizations with a reputational power (Fischer et al. 2009) above or equal 0.50 were coded 1, otherwise 0. Organization having both high organizational capacity and reputational power were coded as 3 , those fulfilling only one of two criteria as 2 , and those meeting neither of the two criteria as 1. Governmental agencies, parliamentary institutions and the residual category (others) were not coded. 